\section{Social Media Adoption for Social CRM in Higher Education: an Insight from Indonesian Universities}

\author{
Meyliana* \\ Faculty of Computer Science \\ University of Indonesia, Depok 16424, Indonesia \\ School of Information Systems \\ Bina Nusantara University, Jakarta 11480, Indonesia \\ meyliana@binus.edumeyliana@ui.ac.id \\ Achmad Nizar Hidayanto \\ Faculty of Computer Science \\ University of Indonesia, Depok 16424, Indonesia \\ nizar@cs.ui.ac.id \\ Eko K. Budiardjo \\ Faculty of Computer Science \\ University of Indonesia, Depok 16424, Indonesia \\ eko@cs.ui.ac.id \\ * Corresponding author
}

\begin{abstract}
A high usage of social media and web 2.0 in Indonesia creates an opportunity for Indonesian universities to understand their customers' demands and needs. By considering social media and web 2.0 technology as an important role for the application of social customer relationship management (social CRM), this research is intended to evaluate the adoption and application level of social media and web 2.0 by universities in Indonesia. We accomplish an observation towards websites and web 2.0 and social media features, which are used by 58 universities in Jakarta, to be analyzed using non-exhaustive Sophistication Index. In addition, we execute a survey as well to take a look on university principals' perception towards the practice of web 2.0 and social media application, and analyze it with Importance Performance Analysis (IPA). The result of this research shows that there are some web 2.0 and social media features which need to be utilized more frequently by universities, though most of these features have been working optimally.
\end{abstract}

Keywords - Social Media, Web 2.0, Social CRM, Non-exhaustive Sophistication Index (SI), Shannon entropy, Importance-Performance Analysis (IPA), Education, Synergy, Research.
Social Media Adoption for Social CRM in Higher Education: an Insight from Indonesian Universities

\section{Psynargía}

International Journal of Synergy and Research Vol. 4, No. 2, 2015 pp. 7-28 
IJSR 4,2

\section{Introduction}

Web/Internet technology has been improving rapidly nowadays. Initially, web technology was only designed to display static and unattractive contents, known as web 1.0. However, technology improvement leads to the technology itself to evolve into web 2.0, which enables global and massive information sharing, collaboration, participation and distribution functions (Patel, 2013). This web 2.0 technology later on drives the occurence of social media, which is a second generation web based on the use of novel technologies, such as RSS (Really Simple Syndication of web contents), podcasting (syndication of audio content), mashups (combination of pre-existing applications), folksonomies (popular labeling or categorizing), widgets (web tools embedded in other sites to perform a particular function) and sharing facilities (options for redistributing the contents of websites to other users) (O'Really as cited in Bonson et al., 2012). A few social media examples are: blogs, social bookmarking, wikis, media sharing as well as social networks that promote collaboration, joint learning and the speedy exchange of information between users (Bonson et al., 2012).

The web 2.0 and social media technology innovation unexceptionally alters the way organizations manage their customers, or what is commonly known as Customer Relationship Management (CRM). The first generation of CRM (known as CRM 1.0) is initally used to manage customer information and utilize it for decision-making in business (Mohan, Choi, and Min, 2008; Greenberg, 2010). The main characteristic of CRM 1.0 is one-way attribute, where organization acts as the ecosystem center, thus the focus is only on internal operational approach to manage customer relationship effectively (customer management). On the second generation of CRM (known as CRM 2.0 or social CRM), the CRM concept shifts by putting customers as priority. Customers are no longer seen as only information consumers, but customers are able to get involved in the product manufacturing process. It is possible because the appearance of social media has changed customers' behaviour in using web, where they have the chance to give complaints on organization's product/service or give positive inputs by collaborating with the organization to create product/service desired by customers (customer engagement) (Greenberg, 2010).

With all advantages offered by social media technology, a lot of organizations have started to exploit social media on various occasions, including customer management. A research by Greenberg (2010) shows how social CRM has contributed positive benefits, especially in creating business value directly by customers, not merely as the central repository for value. For service area like higher education, social CRM should be capitalized particularly to attract prospective student to choose a specific university.

Indonesia is the third largest social media owner in Asia Pacific after China and India (Statistica, 2015), providing an opportunity for universities to make use of web 2.0 and social media. Even though web 2.0 and social media have been proven giving marvelous benefits, a lot of universities are still not exploiting them (Davis III et al., 2012; Reuben, 2008).

By considering the issue, this research is intended to take a look on web 2.0 and social media adoption for social CRM on Indonesian universities. There are two problem focuses in this research: (1) How far is web 2.0 and social media adoption for Social CRM on Indonesian universities? (2) What is the importance level perception of the web 2.0 and social media application for Social CRM on Indonesian universities? 
By accomplishing this research, the adoption of web 2.0 and social media on Social CRM in Indonesian universities can be revealed, and the compatibility between importance level and implementation level of social media on Social CRM can be recognized to be the improvement basis.

\section{Literature Review}

\subsection{Web 2.0 and Social Media}

The term Web 2.0 was coined by O'Really (2005) to refer to a second generation web based on the use of novel technologies, such as RSS (Really Simple Syndication, of web contents), podcasting (syndication of audio content), mashups (combination of preexisting applications), folksonomies (popular labeling or categorizing), widgets (web tools embedded in other sites to perform a particular function) and sharing facilities (options for redistributing the contents of websites to other users).

Web 2.0 definition covers various understandings including the emphasis on usergenerated content, willingness to share data and content, effort to collaborate, new way to interact using web-based application, web usage as social platform to produce, reposition and content usage (Harris and Rea, 2009).

Web 2.0 technologies or what almost universally has been called social media (Burns, 2008) makes the term web 2.0 and social media interchangeable. Social media are various online technology tools which enable people to easily communicate through Internet and share information and resources. Social media can be in the form of text, audio, video, image, podcast and other multimedia communication (Doyle, 2012). The other definition of social media is a group of Internet-based applications which build ideology and Web 2.0 technology foundation, and permit the creation and exchange of User Generated Content (UGC). There are several types of social media like Wikipedia, YouTube, Facebook and Second Life (Kaplan and Haenlein, 2010).

The forms of social media according Patoine (2012) are:

- Blog: user-generated content publication, such as Blogger or WordPress,

- Forum/review sites: peer-to-peer community based on discussion, for instance, Tripadvisor, MoneySupermarket,

- Microblog: brief post (message, photo, link, etc.), like Twitter, Tumblr,

- Social Network: platform which connects people with mutual interest, for example, Facebook, GooglePlus+ or LinkedIn,

- Sharing: platform to share videos, images and other contents, like YouTube, Flickr,

- Other channels: wiki, gaming, podcast, lifecasting, social couponing, such as Wikipedia or Groupon

With the beginning of 2002, came an explosion of social network sites on the web such as Friendster, Facebook, YouTube, Twitter and hundreds of others. Social network sites are web-based services that allow individuals to: (1) construct a public or semi-public profile within a bounded system, (2) articulate a list of other users with whom they share a connection, and (3) view and traverse their list of connections and those made by others within the system (Boyd and Ellison, 2007; Castells, 2013).
Social Media Adoption for Social CRM in Higher Education: an Insight from Indonesian Universities 
IJSR 4,2
On the Internet, organization must consider the strategic implications of the existence of different types of both virtual community and community participation. Strategies for effectively targeting more desirable types of virtual communities and types of community members include: interaction-based segmentation, fragmentation-based segmentation, co-opting communities, paying-for-attention, and building networks by giving product away (Kozinets, 1999).

One of the analysis methods which are used to discern web 2.0 and social media adoption in a website is non-exhaustive Sophistication Index. Non-exhaustive Sophistication Index detects web 2.0 and social media presence, usage and effectivity factors in thirteen variables: (1) podcasts from the management, (2) RSS or ATOM, (3) vodcasts from the management, (4) realtime webcast events, (5) widgets, (6) blogs, (7) links to official YouTube video from the website, (8) social network for the users of the university website, (9) official Twitter account, (10) official Facebook group, (11) official Facebook page, (12) official LinkedIn group and (13) official YouTube channel (Bonson et al., 2012).

\subsection{Social CRM}

Social CRM is a philosophy and a business strategy supported by a technology platform, business rules, processes and social characteristics designed to engage the customer in a collaborative conversation in order to provide mutually beneficial value in a trusted and transparent business environment. It is the company's response to the customer's ownership of the conversation (Greenberg, 2010). Social CRM is commonly known as CRM 2.0 because it is based on Web 2.0 (Askool and Nakata, 2010). The feature and function of Social CRM technology are based on the emotional and behavioral characteristics of human interactions, which are often called social characteristics. Social characteristics are based on the profiles of individuals who are participating in web-based interactions among peers and, for our purposes, between customer and companies (Greenberg, 2010).

Thomas Vander Wal, the creator of social tagging and folsonomies in Greenberg (2010) has developed an approach to the way that human profiles on the web are affected by their actions on each other and the implications of that for business and for web activity. He calls it the social stack. The core components of the social stack are "identify" and "objects". Identify is just what it seems to be - who you are and how you present yourself. The simplest form is your personal profile. Objects are those things that you use to enhance your identity - photos, videos, comments, social tags, ratings and bookmarks. They are often called user-generated content (UGC). While there are two core components, each of them is affected by a separate group of characteristics that affect the way they interact. These are: presence, actions, sharing, reputation, relationships, conversation, groups, collaboration and context (Greenberg, 2010). Social media enables customers to take a more active role as market players and reach (and be reached by) almost everyone anywhere and anytime (Hennig-Thurau et al., 2010)

\subsection{Shannon Entropy}

Shannon (1948) explains that entropy methods can be used not only to quantitatively estimate the number of data, but also to objectively calculate the relative weight of 
information (Hsu and Hsu, 2006). Entropy in information theory is a criterion on uncertainty number represented by discrete probability distribution (Jaynes, 1957 in Hsu and Hsu, 2006). Several researches have utilized entropy method to weigh attributes on case studies such as: the selection of main ingredients supplier (Wardhani, Usadha and Irawan, 2012), the evaluation of water quality in reservoir (Zou, Yun, and Sun, 2006), the determination of critical success factors on health and work safety assurance implemented in organization (Shirouyehzad et al., 2011) and the ERP selection for organization (Asl et al., 2012).

While the weighing steps by using entropy method are as follows:

1. All decision makers provide a value which shows a specific criterion's importance towards the decision-making. Every decision made by them can score according to their own preference.

2. Subtract each number with the most ideal value. The subtraction result is defined as Xij.

3. Divide every Xij with the total value in all criteria to get Pij.

$$
P_{i j}=\frac{X_{i j}}{\sum_{i=1}^{m} X_{i j}}, \quad \forall i, j .
$$

Where $\mathrm{m}=$ number of decision makers

4. Calculate entropy score for every criterion with the following formula:

$$
E_{j}=-k \sum_{i=1}^{m} P_{i j} \ell n P_{i j}, \quad \forall j .
$$

Where $\quad k=\frac{1}{\ell n m}$

Subsequently, count the dispersion of every criterion with the following formula:

$$
d_{j}=1-E_{j}, \quad \forall j .
$$

The total weigh is assumed as 1, thus in order to earn every criterion's weigh, the dispersion value has to be normalized first, therefore:

$$
W_{j}=\frac{d_{j}}{\sum_{j=1}^{n} d_{j}}, \quad \forall j .
$$

Where $\mathrm{n}=$ number of criteria

\subsection{Importance Performance Analysis (IPA)}

At first, Importance Performance Analysis (IPA) method was introduced by Martilla and James (1977) to measure the relationship between customer perception and product/ service quality enhancement priority, known as quadrant analysis (Brandt, 2000; Latu and Everett, 2000). IPA has been publicly accepted and has been used in various study fields due to its convenience and its analysis result display, which eases the suggestion on performance improvement (Martinez, 2003). IPA has the main function to display information related to service factors, which are regarded by customers as influencing their satisfaction and loyalty and the need to be enhanced because the current condition is still not satisfying enough.
Social Media Adoption for Social CRM in Higher

Education: an Insight from Indonesian Universities 
IJSR

4,2

Figure 1.

Divisions of IPA

Quadrants (source:

Brandt, 2000)
IPA combines the measurement of importance level and satisfaction level factors in a two-dimension graphic, which accomodates the explanation of data and practice suggestion. The interpretation of IPA graphic is very simple, it is divided into four quadrants based on measuring result, as seen in Figure 1.

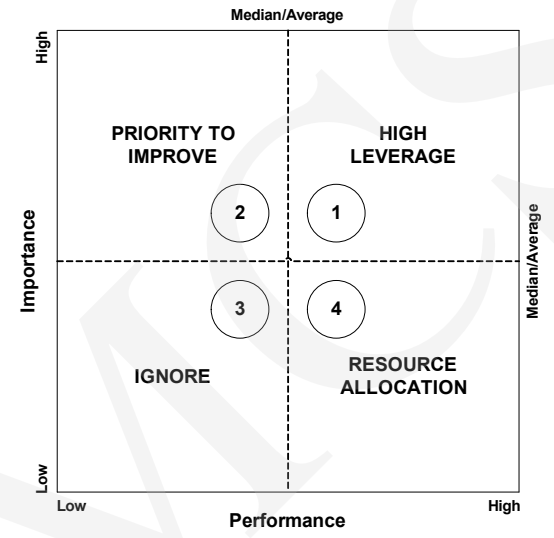

Here is an explanation for each quadrant (Brandt, 2000):

- First Quadrant, "High Leverage" (high importance and high performance)

Factors which are located in this quadrant are considered as supporting factors for customer satisfaction. Thus, the managerial party is obliged to ensure a good maintainance of its institution's performance.

- Second Quadrant, "Priority to Improve" (high importance and low performance) Factors which are located in this quadrant are considered by customers as essential factors, but the current situation is still not satisfying enough. Thus, the managerial party is obliged to allocate qualified resources to improve the performance of those various factors. Factors located in this quadrant have the priority to be enhanced.

- Third Quadrant, "Ignore" (low importance and low performance)

Factors which are located in this quadrant have low satisfaction level and are considered not too important for customers. Thus, the managerial party does not need to prioritize or pay too much attention to those factors.

- Fourth Quadrant, "Resource Allocation" (low importance and high performance)

Factors which are located in this quadrant are considered not too important. Thus, the managerial party needs to allocate resources related to those factors towards other more prioritized factors, for instance, in the second quadrant.

There are two types of methods to display IPA data (Martinez, 2003): first, by placing quadrant intersection line on the median of the valuation scale, which is used in satisfaction level axis and handling priority axis, in order to generally find out in which quadrant the data is spread; and second by placing quadrant intersection line on the average of satisfaction level axis and handling priority axis in order to specifically find out in which quadrant each factor is located. The procedures related to IPA method usage are as follows: 
- determining which factors are going to be analyzed,

- completing survey by spreading questionnaire,

- calculating average value of satisfaction level and handling priority level,

- creating IPA graph,

- evaluating factors in every quadrants.

\section{Methodology}

This research is accomplished by using two approaches: observation and survey towards 58 private universities in Jakarta. Private universities are selected due to high difficulty level in recruiting new students. The selection of the 58 private universities is done by considering Webometric ranking, 4ICU ranking and recognition given by the government as top universities.

Observation is done to analyze universities' adoption level towards web 2.0 and social media by observing universities' websites and web 2.0 and social media features which are used by the universities. The observed elements are adapted from non-exhaustive sophistication index (SI), which are frequently used to analyze e-government adoption (Bonson et al., 2012) and covers 13 variables: (1) podcasts from the management, (2) RSS or ATOM, (3) vodcasts from the management, (4) realtime webcast events, (5) widgets, (6) blogs, (7) links to official YouTube video from the website, (8) social network for the users of the university website, (9) official Twitter account, (10) official Facebook group, (11) official Facebook page, (12) official LinkedIn group and (13) official YouTube channel (Bonson et al., 2012).

A survey is fulfilled to see the compatibility between importance and implementation level on universities and to provide recommendation for improvement needed in implementing Social CRM. Importance level will be analyzed based on weighing/ ranking with Shannon entropy method, while compatibility level will be measured by using Importance Performance Analysis (IPA) method. The research instruments in this survey is a questionnaire, where the dimension/indicator is revealed from social stack theory (web 2.0 and social media feature) by Greenberg (2010) and can be seen in the following Table 1. The usage of web 2.0 feature on social stack does not convey completely from non-exhaustive Sophistication Index variable by Bonson et al. (2012).

\section{Results and Discussions}

The adoption of web 2.0 and social media on universities' websites and the analysis of social media function importances on social CRM in Indonesia will be discussed in Results and Discussions.

\subsection{Web 2.0 and Social Media Adoption on Universities' Websites} According to non-exhaustive sophistication index (SI) analysis, which can be seen in the following Table 2, it is explained that most universities' websites have realtime webcast of events $(98.28 \%)$. It means that only one website does not use this feature. 
Pobrane z czasopisma International Journal of Synergy and Research http://ijsr.journals.umcs.pl

Data: 26/04/2023 04:26:56

14

IJSR

4,2

\begin{tabular}{|c|c|c|c|c|c|}
\hline Variable & $\begin{array}{c}\text { Sub } \\
\text { Variable }\end{array}$ & $\begin{array}{l}\text { Dimension/ } \\
\text { Indicator }\end{array}$ & $\begin{array}{l}\text { Dimension/ } \\
\text { Indicator Description }\end{array}$ & References & $\begin{array}{l}\text { Dimension/ } \\
\text { Indicator } \\
\text { No }\end{array}$ \\
\hline Social Media & & & $\begin{array}{l}\text { Various online technology tools which } \\
\text { enable people to easily communicate } \\
\text { through internet and share informations } \\
\text { and resources. This social media can } \\
\text { be in the form of text, audio, video, } \\
\text { image, podcast, and other multimedia } \\
\text { communications. Own social media } \\
\text { accounts }\end{array}$ & $\begin{array}{l}\text { Doyle, } 2012 \\
\text { Greenberg, } 2010: 41\end{array}$ & 1 \\
\hline \multirow[t]{3}{*}{$\begin{array}{l}\text { Social Media } \\
\text { Social Media }\end{array}$} & \multirow[t]{2}{*}{ Identify } & & $\begin{array}{l}\text { Someone's profile in web is influenced } \\
\text { by his/her action to one another, and the } \\
\text { implication towards web business and } \\
\text { activities }\end{array}$ & Greenberg, 2010:41 & \\
\hline & & $\begin{array}{l}\text { Identify/ } \\
\text { Profile }\end{array}$ & $\begin{array}{l}\text { What is seen -- who are you and how do } \\
\text { you show yourself? }\end{array}$ & $\begin{array}{l}\text { Greenberg, 2010:41 } \\
\text { Mohan, Choi \& Min, 2008: } 239 \\
\text { Olivera, Sita \& Sasa, 2013:347, } \\
\text { 348, } 351 \\
\text { Mousavi \& Demirkan, 2013: } 718 \\
\text { Heath, Singh \& Ganesh, 2014:589 }\end{array}$ & 2 \\
\hline & Object & & $\begin{array}{l}\text { Something used to clarify self } \\
\text { identification }\end{array}$ & $\begin{array}{l}\text { Greenberg, 2010:41 } \\
\text { Heath, Singh \& Ganesh, 2014:591 } \\
\text { Olivera, Sita \& Sasa, 2013:350 }\end{array}$ & \\
\hline & $\begin{array}{l}\text { Object } \\
\text { Object }\end{array}$ & Photos & $\begin{array}{l}\text { Self image or certain image which shows } \\
\text { what to be shared to others }\end{array}$ & $\begin{array}{l}\text { Greenberg, 2010:41 } \\
\text { Mohan, Choi \& Min, 2008: } 239 \\
\text { Dukić, Meler \& Mesarić, 2009:116 } \\
\text { Olivera, Sita \& Sasa, 2013:348 }\end{array}$ & 3 \\
\hline & & Videos & Digitally-moved visual graphic record & $\begin{array}{l}\text { Greenberg, 2010:41 } \\
\text { Dukić, Meler \& Mesarić, 2009:116 } \\
\text { Olivera, Sita \& Sasa, 2013:349, } 351 \\
\text { Mousavi \& Demirkan, 2013: 718, } 719\end{array}$ & 4 \\
\hline & & Comments & $\begin{array}{l}\text { Word or sentence which is written to } \\
\text { express opinion or reaction }\end{array}$ & $\begin{array}{l}\text { Greenberg, 2010:41 } \\
\text { Mohan, Choi \& Min, 2008: } 242 \\
\text { Olivera, Sita \& Sasa, 2013:351 } \\
\text { Mousavi \& Demirkan, 2013: } 718\end{array}$ & 5 \\
\hline & & $\begin{array}{l}\text { Social tags/ } \\
\text { folksonomies }\end{array}$ & $\begin{array}{l}\text { System which is processed by user to } \\
\text { classify and manage online contents into } \\
\text { different categories by using meta data, } \\
\text { such as electronic tags }\end{array}$ & $\begin{array}{l}\text { Greenberg, 2010:41 } \\
\text { Mohan, Choi \& Min, 2008: } 240\end{array}$ & 6 \\
\hline & & Ratings & $\begin{array}{l}\text { Classification or ranking based on } \\
\text { comparison score of quality, standard, or } \\
\text { performance }\end{array}$ & $\begin{array}{l}\text { Greenberg, 2010:41 } \\
\text { Mohan, Choi \& Min, 2008: } 240\end{array}$ & 7 \\
\hline & & Bookmarks & $\begin{array}{l}\text { Record of website address, file, etc. to } \\
\text { ease the access afterwards }\end{array}$ & Greenberg, 2010:41 & 8 \\
\hline & & Reviews & $\begin{array}{l}\text { Formal scoring or testing on something } \\
\text { with certain intention }\end{array}$ & $\begin{array}{l}\text { Greenberg, 2010:41 } \\
\text { Heath, Singh \& Ganesh, 2014:587 }\end{array}$ & 9 \\
\hline & & $\begin{array}{l}\text { Rankings/ } \\
\text { Indexed }\end{array}$ & $\begin{array}{l}\text { Position or classification in achievement } \\
\text { or status scale }\end{array}$ & $\begin{array}{l}\text { Greenberg, 2010:41 } \\
\text { Mohan, Choi \& Min, 2008: } 240\end{array}$ & 10 \\
\hline
\end{tabular}

Dimension/Indicator in

Research Instrument 
Pobrane z czasopisma International Journal of Synergy and Research http://ijsr.journals.umcs.pl

Data: 26/04/2023 04:26:56

\begin{tabular}{|c|c|c|c|c|c|}
\hline Variable & $\begin{array}{c}\text { Sub } \\
\text { Variable }\end{array}$ & $\begin{array}{l}\text { Dimension/ } \\
\text { Indicator }\end{array}$ & $\begin{array}{l}\text { Dimension/ } \\
\text { Indicator Description }\end{array}$ & References & $\begin{array}{c}\text { Dimension/ } \\
\text { Indicator } \\
\text { No }\end{array}$ \\
\hline & & Blogs & $\begin{array}{l}\text { Web-based journal, an account } \\
\text { consisting events/thoughts/ideas which } \\
\text { can be written individually or sometimes } \\
\text { by a group of people. It is commonly } \\
\text { used by companies to brand or to reach } \\
\text { customers internally to discuss ideas/ } \\
\text { documents in the team. }\end{array}$ & $\begin{array}{l}\text { Greenberg, 2010:127 } \\
\text { Mohan, Choi \& Min, 2008: } 240 \\
\text { Heath, Singh \& Ganesh, 2014:585, } 588 \\
\text { Olivera, Sita \& Sasa, 2013:348, } 351 \\
\text { Mousavi \& Demirkan, 2013: } 725\end{array}$ & 11 \\
\hline & & Wikis & $\begin{array}{l}\text { Website which allows user to edit a } \\
\text { content together all at one time }\end{array}$ & $\begin{array}{l}\text { Greenberg, 2010:127 } \\
\text { Mohan, Choi \& Min, 2008: } 240 \\
\text { Olivera, Sita \& Sasa, 2013:351 }\end{array}$ & 12 \\
\hline & & Podcasts & $\begin{array}{l}\text { Audio file which uses RSS (Really Simple } \\
\text { Syndication) to distribute broadcasts } \\
\text { to customers, or allow customers to } \\
\text { download them into computer or } \\
\text { portable music device }\end{array}$ & Greenberg, 2010:129 & 13 \\
\hline & & Mail & $\begin{array}{l}\text { Electronic mail which ease the sending } \\
\text { and receiving process }\end{array}$ & $\begin{array}{l}\text { Mohan, Choi \& Min, 2008: } 240 \\
\text { Mousavi \& Demirkan, 2013: } 718\end{array}$ & 14 \\
\hline & & Forums & $\begin{array}{l}\text { Media to trade idea, knowledge, and } \\
\text { perception regarding certain thing/issue }\end{array}$ & $\begin{array}{l}\text { Mohan, Choi \& Min, 2008: 242 } \\
\text { Dukić, Meler \& Mesarić, 2009:116, } 117 \\
\text { Olivera, Sita \& Sasa, 2013:348, 349, } \\
351\end{array}$ & 15 \\
\hline & & $\begin{array}{l}\text { Presence/ } \\
\text { Instant } \\
\text { Messaging }\end{array}$ & $\begin{array}{l}\text { Allow us to know how others would } \\
\text { like to be contacted when they are } \\
\text { online. IM is defined as an one-on-one } \\
\text { communication assisting tool. IM has } \\
\text { unique features such as: real-time } \\
\text { trading on text,file,graph, graphic } \\
\text { icon, contact list, presence awareness, } \\
\text { "pop up" recipient notification, and } \\
\text { polychromic communication }\end{array}$ & $\begin{array}{l}\text { Greenberg, 2010:42 } \\
\text { Chen, 2009:518 } \\
\text { Heath, Singh \& Ganesh, 2014:587 } \\
\text { Mousavi \& Demirkan, 2013: } 725\end{array}$ & 16 \\
\hline & & Actions & $\begin{array}{l}\text { Direct action, for example: uploading } \\
\text { photo, leaving comment on video, } \\
\text { sending message, etc }\end{array}$ & $\begin{array}{l}\text { Greenberg, 2010:42 } \\
\text { Bekmamedova \& Shanks, } \\
\text { 2014:3730, 3732, 3734, 3735 } \\
\text { Heath, Singh \& Ganesh, 2014:584- } \\
\text { 586, 588-593 } \\
\text { Olivera, Sita \& Sasa, 2013:347, } 348\end{array}$ & 17 \\
\hline & & Sharing & $\begin{array}{l}\text { Single element which is considered } \\
\text { valuable when it is shared to others, for } \\
\text { instance: a video on how to survive from } \\
\text { tsunami/earthquake, etc }\end{array}$ & $\begin{array}{l}\text { Greenberg, 2010:42 } \\
\text { Mohan, Choi \& Min, 2008: } 240 \\
\text { Olivera, Sita \& Sasa, 2013:348 } \\
\text { Mousavi \& Demirkan, 2013: } 718\end{array}$ & 18 \\
\hline & & Reputation & $\begin{array}{l}\text { Trust level towards others. Reputation } \\
\text { can be boosted through individual } \\
\text { participation in cooperative environment } \\
\text { like wiki or community }\end{array}$ & $\begin{array}{l}\text { Greenberg, 2010:43 } \\
\text { Bekmamedova \& Shanks, } \\
\text { 2014:3730, 3732, } 3733\end{array}$ & 19 \\
\hline
\end{tabular}

Social Media Adoption

for Social CRM in Higher

Education: an

Insight from

Indonesian

Universities
Table 1.

Continuation 
Pobrane z czasopisma International Journal of Synergy and Research http://ijsr.journals.umcs.pl

Data: 26/04/2023 04:26:56

IJSR

4,2

\begin{tabular}{|c|c|c|c|c|c|}
\hline Variable & $\begin{array}{c}\text { Sub } \\
\text { Variable }\end{array}$ & $\begin{array}{l}\text { Dimension/ } \\
\text { Indicator }\end{array}$ & $\begin{array}{l}\text { Dimension/ } \\
\text { Indicator Description }\end{array}$ & References & $\begin{array}{l}\text { Dimension/ } \\
\text { Indicator } \\
\text { No }\end{array}$ \\
\hline & & Relationships & $\begin{array}{l}\text { Interaction among humans which choose } \\
\text { to get involved based on its reputation. } \\
\text { People trust result from an action }\end{array}$ & $\begin{array}{l}\text { Greenberg, 2010:42 } \\
\text { Mohan, Choi \& Min, 2008: } 239 \\
\text { Heath, Singh \& Ganesh, 2014:584, } \\
\text { 590, } 592 \\
\text { Olivera, Sita \& Sasa, 2013:347, } \\
\text { 348, } 352\end{array}$ & 20 \\
\hline & & Conversation & $\begin{array}{l}\text { Relationship between companies and } \\
\text { customers has been shifting, where } \\
\text { companies initially push their products } \\
\text { to customers. Currently, it has become } \\
\text { a conversation between companies and } \\
\text { customers. This means customers work } \\
\text { together with companies to create a } \\
\text { suitable and valuable experience for } \\
\text { customers, and companies will get profit } \\
\text { in return }\end{array}$ & $\begin{array}{l}\text { Greenberg, 2010:44 } \\
\text { Bekmamedova \& Shanks, } \\
\text { 2014:3731 } \\
\text { Heath, Singh \& Ganesh, 2014:585, } \\
588,589\end{array}$ & 21 \\
\hline & & Groups & $\begin{array}{l}\text { Usually called as community with mutual } \\
\text { interest/practice, consisting of people } \\
\text { who } \\
\text { interact one another on certain domain, } \\
\text { for example: profession club }\end{array}$ & $\begin{array}{l}\text { Greenberg, 2010:44 } \\
\text { Mohan, Choi \& Min, 2008: 242 } \\
\text { Heath, Singh \& Ganesh, 2014:590, } \\
592 \\
\text { Olivera, Sita \& Sasa, 2013:347-351 } \\
\text { Mousavi \& Demirkan, 2013: } 720\end{array}$ & 22 \\
\hline & & Communities & $\begin{array}{l}\text { A group of people who has a specific } \\
\text { mutual characteristic }\end{array}$ & $\begin{array}{l}\text { Mohan, Choi \& Min, 2008: } 242 \\
\text { Heath, Singh \& Ganesh, 2014:588 } \\
\text { Olivera, Sita \& Sasa, 2013:351 } \\
\text { Mousavi \& Demirkan, 2013: } 720\end{array}$ & 23 \\
\hline & & $\begin{array}{l}\text { Collabora- } \\
\text { tion }\end{array}$ & $\begin{array}{l}\text { Relationship of one another which gives } \\
\text { valuable benefits }\end{array}$ & $\begin{array}{l}\text { Greenberg, 2010:44 } \\
\text { Mohan, Choi \& Min, 2008: } 240\end{array}$ & 24 \\
\hline & & Context & $\begin{array}{l}\text { How a previously-made profile will be } \\
\text { used to define what is intended, what } \\
\text { is seen, and how it is seen, for instance: } \\
\text { status is made to let other people know } \\
\text { what we need }\end{array}$ & $\begin{array}{l}\text { Greenberg, 2010:45 } \\
\text { Bekmamedova \& Shanks, } \\
\text { 2014:3730, } 3732 \\
\text { Heath, Singh \& Ganesh, 2014:585, } \\
\text { 588, 589, } 590 \\
\text { Olivera, Sita \& Sasa, 2013:348 } \\
\text { Olivera, Sita \& Sasa, 2013:351 } \\
\text { Mousavi \& Demirkan, 2013: } \\
\text { 718-724 }\end{array}$ & 25 \\
\hline
\end{tabular}

Table 1.

Continuation 
The most adopted feature by all universities' websites is widgets (89.66\%). Widgets feature significantly helps customers to access all applications in the website. However, podcast from management feature has not been implemented in any websites yet $(0.00 \%)$. This issue occurs because generally websites still have text displaying message/greeting by the universities' management (rector/head/director).

(2010) has developed an approach to the way that human profiles on the web are affected by their actions on each other and the implications of that for business and for web activity. He calls it the social stack. The core components of the social stack are "identify" and "objects". Identify is just what it seems to be - who you are and how you present yourself. The simplest form is your personal profile. Objects are those things that you use to enhance your identity - photos, videos, comments, social tags, ratings and bookmarks. They are often called user-generated content (UGC). While there are two core components, each of them is affected by a separate group of characteristics that affect the way they interact. These are: presence, actions, sharing, reputation, relationships, conversation, groups, collaboration and context (Greenberg, 2010). Social media enables customers to take a more active role as market players and reach (and be reached by) almost everyone anywhere and anytime (Hennig-Thurau et al., 2010)

\subsection{Shannon Entropy}

Shannon (1948) explains that entropy methods can be used not only to quantitatively estimate the number of data, but also to objectively calculate the relative weight of

information (Hsu and Hsu, 2006). Entropy in information theory is a criterion on uncertainty number represented by discrete probability distribution (Jaynes, 1957 in Hsu and Hsu, 2006). Several researches have utilized entropy method to weigh attributes on case studies such as: the selection of main ingredients supplier (Wardhani, Usadha and Irawan, 2012), the evaluation of water quality in reservoir (Zou, Yun, and Sun, 2006), the determination of critical success factors on health and work safety assurance implemented in organization (Shirouyehzad et al., 2011) and the ERP selection for organization (Asl et al., 2012).

While the weighing steps by using entropy method are as follows:

1. All decision makers provide a value which shows a specific criterion's importance towards the decision-making. Every decision made by them can score according to their own preference.

2. Subtract each number with the most ideal value. The subtraction result is defined as Xij.

3. Divide every $\mathrm{Xij}$ with the total value in all criteria to get Pij.

$$
P_{i j}=\frac{X_{i j}}{\sum_{i=1}^{m} X_{i j}}, \quad \forall i, j .
$$

Social Media Adoption

for Social CRM in Higher

Education: an Insight from Indonesian Universities 
Pobrane z czasopisma International Journal of Synergy and Research http://ijsr.journals.umcs.pl Data: 26/04/2023 04:26:56

18

\section{IJSR}

4,2

Table 2.

Continuation

Table 3.

Non-exhaustive

Sophistication Index

\begin{tabular}{|c|c|c|c|c|c|c|c|c|c|c|c|c|c|c|c|c|c|c|c|c|}
\hline \multirow{2}{*}{$\begin{array}{l}\text { No The usage of university } \\
\text { website }\end{array}$} & \multicolumn{18}{|c|}{ Private Higher Educations } & \multirow[t]{2}{*}{ Total } & \multirow[t]{2}{*}{$\%$} \\
\hline & 41 & 42 & 43 & 44 & 45 & 46 & 47 & 48 & 49 & 50 & 51 & 52 & 53 & 54 & 55 & 56 & 57 & 58 & & \\
\hline $\begin{array}{l}1 \text { Podcast from the } \\
\text { management }\end{array}$ & 0 & 0 & 0 & 0 & 0 & 0 & 0 & 0 & 0 & 0 & 0 & 0 & 0 & 0 & 0 & 0 & 0 & 0 & 0 & 0.0 \\
\hline 2 RSS or Atom & 1 & 0 & 0 & 0 & 1 & 1 & 0 & 1 & 1 & 0 & 0 & 0 & 0 & 0 & 0 & 1 & 0 & 0 & 20 & $34.48 \%$ \\
\hline $\begin{array}{l}3 \text { Vodcast from the } \\
\text { management }\end{array}$ & 1 & 0 & 0 & 1 & 0 & 1 & 0 & 0 & 1 & 1 & 0 & 0 & 0 & 1 & 0 & 1 & 0 & 0 & 30 & $1.72 \%$ \\
\hline 4 Realtime webcast of events & 1 & 1 & 1 & 1 & 1 & 1 & 1 & 1 & 1 & 1 & 1 & 1 & 1 & 1 & 1 & 1 & 1 & 1 & 57 & $98.28 \%$ \\
\hline 5 Widgets & 1 & 1 & 1 & 1 & 1 & 1 & 1 & 1 & 1 & 1 & 1 & 1 & 1 & 1 & 1 & 1 & 1 & 1 & 52 & $89.66 \%$ \\
\hline 6 Blogs & 1 & 0 & 0 & 0 & 0 & 0 & 1 & 0 & 1 & 0 & 0 & 0 & 1 & 0 & 0 & 1 & 1 & 0 & 21 & $36.21 \%$ \\
\hline $\begin{array}{l}7 \text { Links to official YouTube } \\
\text { videos }\end{array}$ & 1 & 0 & 0 & 1 & 0 & 1 & 0 & 0 & 1 & 1 & 0 & 0 & 0 & 1 & 0 & 1 & 0 & 0 & 26 & $44.83 \%$ \\
\hline $\begin{array}{l}8 \text { Social network for the users } \\
\text { of the university website }\end{array}$ & 1 & 1 & 1 & 1 & 0 & 1 & 1 & 1 & 1 & 1 & 0 & 1 & 1 & 1 & 1 & 1 & 1 & 1 & 39 & $67.24 \%$ \\
\hline 9 Official Twitter account & 1 & 1 & 1 & 1 & 1 & 1 & 1 & 0 & 1 & 1 & 0 & 1 & 0 & 1 & 1 & 1 & 1 & 1 & 41 & $70.69 \%$ \\
\hline 10 Official Facebook group & 0 & 0 & 0 & 1 & 0 & 0 & 0 & 0 & 1 & 0 & 1 & 0 & 0 & 0 & 1 & 0 & 0 & 0 & 19 & $32.76 \%$ \\
\hline 11 Official Facebook page & 1 & 1 & 1 & 1 & 1 & 1 & 1 & 1 & 1 & 1 & 1 & 1 & 1 & 1 & 1 & 1 & 1 & 1 & 58 & $100.00 \%$ \\
\hline 12 0fficial Linkedln group & 1 & 1 & 1 & 1 & 1 & 1 & 1 & 1 & 1 & 1 & 1 & 1 & 0 & 1 & 0 & 1 & 1 & 1 & 49 & $84.48 \%$ \\
\hline 13 Official Youtube channel & 1 & 0 & 0 & 1 & 0 & 1 & 0 & 0 & 1 & 1 & 0 & 0 & 0 & 1 & 0 & 1 & 0 & 0 & 30 & $51.72 \%$ \\
\hline
\end{tabular}

\begin{tabular}{|c|c|c|c|c|c|}
\hline & & & & \multicolumn{2}{|c|}{ Universities (58) } \\
\hline & & & & $\mathbf{N}$ & $\%$ \\
\hline \multirow{13}{*}{$\begin{array}{l}\text { Sophistication } \\
\text { Index }\end{array}$} & Web 2.0 & Official Website & Podcast from the management & 0 & $0.00 \%$ \\
\hline & & & RSS or Atom & 20 & $34.48 \%$ \\
\hline & & & Vodcast from the management & 30 & $51.72 \%$ \\
\hline & & & Realtime webcast of events & 57 & $98.28 \%$ \\
\hline & & & Widgets & 52 & $89.66 \%$ \\
\hline & Social Media & & Blogs & 21 & $36.21 \%$ \\
\hline & & & Links to official YouTube videos & 26 & $44.83 \%$ \\
\hline & & & $\begin{array}{l}\text { Social network for the users of the } \\
\text { university website }\end{array}$ & 39 & $67.24 \%$ \\
\hline & & External Channels & Official Twitter account & 41 & $70.69 \%$ \\
\hline & & & Official Facebook group & 19 & $32.76 \%$ \\
\hline & & & Official Facebook page & 58 & $100.00 \%$ \\
\hline & & & Official Linkedln group & 49 & $84.48 \%$ \\
\hline & & & Official Youtube channel & 30 & $51.72 \%$ \\
\hline
\end{tabular}

Summary data on non-exhaustive Sophistication Index can be seen in the following Table 3 .

From the social media point of view, only $67.24 \%$ (39 from 58) universities publish social media link on their official websites. The common social media are Facebook, Twitter, LinkedIn and YouTube. All universities (100\%) utilize Facebook fanpage (58 from 58) and only 19 universities utilize Facebook group (32.76\%). The next most 
commonly-used social media are LinkedIn group (84.48\%) and Twitter $(70.69 \%)$. YouTube channel is used as well as vodcast from management by $51.72 \%$.

According to the observation towards universities' activities on facebook social media, there are sixteen universities which update daily information (daily activities); seven universities which update weekly activities; nine universities which update monthly activities; four universities which update quarterly activities; eight universities which update annual activities; and fifteen universities which do not have any update at all on their Facebook (no activity).

Meanwhile in the Twitter social media observation towards forty-one universities which have a Twitter account, there are eleven universities which update (tweet) daily information (daily activities); eight universities which update weekly activities; four that update monthly activities; six universities which update quarterly activities; one university which updates semestral activities; one university which updates annual activities; and ten universities which do not have any update (tweet) at all in their Twitter accounts (no activity). The detailed social media usage can be seen in the following Table 4 .

Table 4 shows that social media has been started to be utilized. The number of followers in Twitter reach 8,318 on average and the number of fans in Facebook page reach 10,004 on average. Moreover, Twitter and Facebook activity are the most frequently operated social media (daily-based).

\begin{tabular}{llc}
\hline & \multicolumn{1}{c}{ Social Media Metrics } & Mean/Amount \\
\hline & Universities with an official Twitter account & $41(70.69 \%)$ \\
& Average number of Twitter followers & 8318 \\
& Average number of Twitter tweets & 2378 \\
& Average number of Twitter lists & 0.44 \\
& Activity of the official Twitter account & 7 \\
\hline & Average number of Facebook groups & 1 \\
& Universities with an official Facebook group & $19(31.76 \%)$ \\
& Average number of members of the official Facebook group & 663 \\
& Average number of Facebook pages & 2 \\
& Universities with an official Facebook page & $58(100 \%)$ \\
& Average number of fans of the official Facebook page & 10004 \\
& Activity of the official Facebook page & 7 \\
\hline & Average number of Linkedln groups & 1 \\
& Universities with an official Linkedln group & 7054 \\
\hline & Average number of members of the official Linkedln group & 2569 \\
\hline & Universities with an official YouTube channel & $30(51.72 \%)$ \\
\hline & Average number of subscribers to the official YouTube channel & 14 \\
\hline & Average number of YouTube conversations & $78 \%)$ \\
\hline
\end{tabular}

Social Media Adoption for Social CRM in Higher Education: an Insight from Indonesian Universities
Table 4.

Social media usage on universities (social media metrics) 
IJSR

4,2
Table 5.

Result of Shannon

Entropy calculation for weighting/ranking

\subsection{Analysis of Social Media Function Usage-Importance on Social CRM}

Among fifty-eight private universities in Indonesia which have been sent questionnaire, seventeen of them returned the questionnaire. Survey is accomplished to see the compatibility between importance and application level on universities and to give recommendation for improvement needed in implementing Social CRM.

Importance level is analyzed based on weighing/ranking with Shannon Entropy method to observe which factor is considered the most fundamental by respondents in implementing social media on universities. The result of Shannon Entropy calculation can be seen in the following Table 5 .

According to the Table 5 above, it is clearly seen that respondent universities consider owning social media account essential as well as publishing universities' identity, official photos and official video (4th highest rank). It does make sense because social media's

\begin{tabular}{|c|c|c|}
\hline Questionnaire No & Entropy Value & Dimention/Indicator \\
\hline 1 & 0.041874 & Social media account \\
\hline 2 & 0.041874 & Institution identity \\
\hline 3 & 0.041656 & Official photos \\
\hline 4 & 0.041176 & Official videos \\
\hline 20 & 0.040495 & Relationship \\
\hline 8 & 0.040423 & Bookmarks \\
\hline 19 & 0.040378 & Reputation \\
\hline 25 & 0.04035 & Context \\
\hline 5 & 0.040305 & Comments \\
\hline 15 & 0.040278 & Forum \\
\hline 16 & 0.04016 & Presence/instant mesaging \\
\hline 21 & 0.040088 & Conversation \\
\hline 18 & 0.039915 & Sharing \\
\hline 11 & 0.039876 & Blogs \\
\hline 9 & 0.039849 & Review \\
\hline 7 & 0.039625 & Rating \\
\hline 24 & 0.03958 & Collaboration \\
\hline 6 & 0.039408 & Social tags/folksonomies \\
\hline 23 & 0.039407 & Communities \\
\hline 10 & 0.039396 & Ranking/indexing \\
\hline 14 & 0.039262 & Email \\
\hline 22 & 0.039189 & Groups \\
\hline 13 & 0.039044 & Podcasts \\
\hline 12 & 0.038664 & Wikis \\
\hline 17 & 0.037726 & Actions \\
\hline
\end{tabular}


basic contents are the account owner's name, photos and video. The next 5th-10th rank in correct order are: relationship, bookmarks, reputation, context, comments and forum. Respondents see that the main goal of using social media is to maintain relationship. Contents classification (bookmarks) inside is very helpful for the account owner to look for or find the desired content. The foundation of relationship in social media is based on trust grown by the account owner's reputation. This reputation is formed based on context such as: status made by the account's owner, shared information and especially comments given to both him/herself or others. Forum establishment is often done to assist the communication among parties with a mutual importance, interest, hobby or similarity and to provide open communication to help finding information.

Compatibility level is measured using importance-performance analysis (IPA) method. IPA method uses 2 approaches which produce similar result. The first IPA method needs every dimension/indicator to be mapped into the intersection quadrant of importance and implementation axis using the median and the mean, as can be seen in the following Table 6 and Figure 2.

\begin{tabular}{|c|c|c|c|c|c|}
\hline No & \begin{tabular}{|c|} 
Performance \\
(X)
\end{tabular} & $\begin{array}{c}\text { Inportance } \\
\text { (Y) }\end{array}$ & Gap (X-Y) & \begin{tabular}{c|} 
Median \\
Quadrant
\end{tabular} & $\begin{array}{c}\text { Mean } \\
\text { Quadrant }\end{array}$ \\
\hline 1 & 5.294117647 & 5.823529412 & -0.529411765 & 1 & 1 \\
\hline 2 & 5.647058824 & 5.823529412 & -0.176470588 & 1 & 1 \\
\hline 3 & 5.647058824 & 5.823529412 & -0.176470588 & 1 & 1 \\
\hline 4 & 5.117647059 & 5.647058824 & -0.529411765 & 1 & 1 \\
\hline 5 & 5.117647059 & 5.470588235 & -0.352941176 & 1 & 1 \\
\hline 6 & 3.470588235 & 5.176470588 & -1.705882353 & 2 & 3 \\
\hline 7 & 3.764705882 & 5.235294118 & -1.470588235 & 1 & 3 \\
\hline 8 & 4.352941176 & 5.352941176 & -1 & 1 & 1 \\
\hline 9 & 3.882352941 & 5.117647059 & -1.235294118 & 1 & 3 \\
\hline 10 & 3.529411765 & 4.941176471 & -1.411764706 & 1 & 3 \\
\hline 11 & 3.764705882 & 5.117647059 & -1.352941176 & 1 & 3 \\
\hline 12 & 3.058823529 & 4.823529412 & -1.764705882 & 2 & 3 \\
\hline 13 & 3.470588235 & 4.941176471 & -1.470588235 & 2 & 3 \\
\hline 14 & 4.058823529 & 5.176470588 & -1.117647059 & 1 & 3 \\
\hline 15 & 3.882352941 & 5.411764706 & -1.529411765 & 1 & 2 \\
\hline 16 & 4 & 5.352941176 & -1.352941176 & 1 & 2 \\
\hline 17 & 3.705882353 & 4.470588235 & -0.764705882 & 1 & 3 \\
\hline 18 & 4.058823529 & 5.117647059 & -1.058823529 & 1 & 3 \\
\hline 19 & 4.705882353 & 5.411764706 & -0.705882353 & 1 & 1 \\
\hline 20 & 4.294117647 & 5.470588235 & -1.176470588 & 1 & 1 \\
\hline 21 & 4.058823529 & 5.294117647 & -1.235294118 & 1 & 2 \\
\hline 22 & 3.705882353 & 5.117647059 & -1.411764706 & 1 & 3 \\
\hline 23 & 3.764705882 & 5.117647059 & -1.352941176 & 1 & 3 \\
\hline 24 & 4.294117647 & 5.294117647 & \begin{tabular}{l|}
-1 \\
\end{tabular} & 1 & 1 \\
\hline 25 & 4.588235294 & 5.411764706 & -0.823529412 & 1 & 1 \\
\hline Median & 3.5 & 3.5 & & & \\
\hline Mean & 4.209411765 & 5.277647059 & -1.068235294 & 1 & \\
\hline
\end{tabular}

\begin{tabular}{lcccc}
\hline \multicolumn{1}{c}{ Description } & Performance & Frequency & Percentage & $(\%)$ \\
\hline 1. HIGH LEVERAGE & + & + & 22 & $88 \%$ \\
2. PRIORITY TO IMPROVE & + & - & 3 & $12 \%$ \\
3. IGNORE & - & - & 0 & $0 \%$ \\
4. RESOURCE ALLOCATION & - & + & 0 & $0 \%$ \\
\hline & & TOTAL & 25 & $100 \%$ \\
\hline
\end{tabular}

Social Media Adoption for Social CRM in Higher Education: an Insight from Indonesian Universities 
IJSR

\section{4,2}

\section{Figure 2.}

Importance-Performance Analysis (IPA) - media axis (above), mean axis (below)

\section{Table 7.}

IPA scenario based on respondents' valuation

Based on the Table 6, there are three dimensions/indicators which are located in the second quadrant (priority to improve): social tags/folksonomies (No. 6), wikis (No. 12) and podcast (No. 13) highlighted using red symbol in Figure 2. This data is in harmony with the observation done towards universities' websites in Sophistication Index (SI), where podcast has not been the main feature because universities are still depending on greetings/messages in text form (see Table 3). The detailed image of quadrant mapping on this gap analysis can be seen in Figure 2.
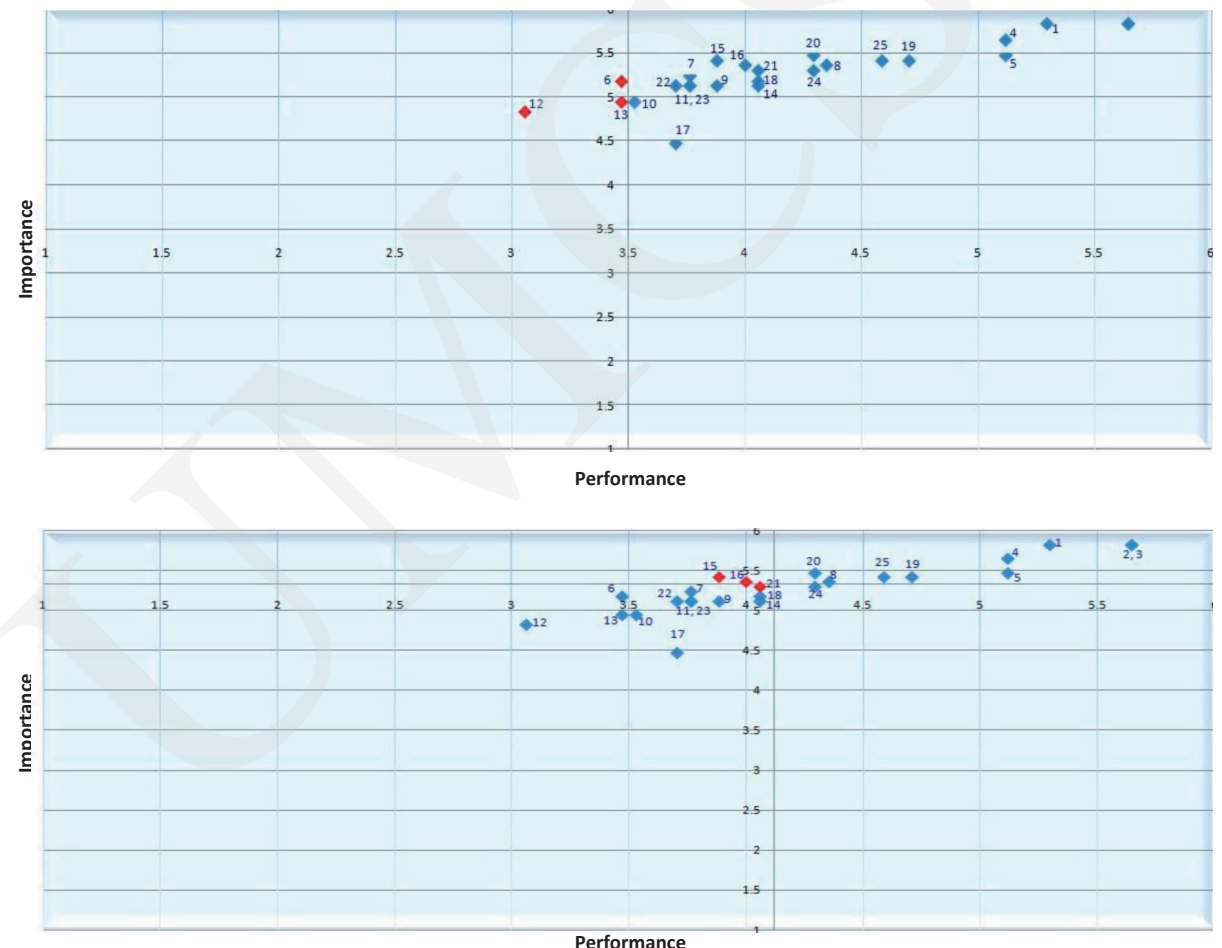

The second IPA method uses respondent valuation approach, which is divided into two parts, namely 1-3 for low valuation and 4-6 for high valuation (Sigala and Chalkiti, 2014). Each of these valuations are mapped based on the importance and implementation into 4 scenarios: (A) indifference (low performance, low importance), (B) wasting time and resources (high performance, low importance), (C) missing opportunity/gap (low performance, high importance) and (D) effective use (high performance, high importance) as seen in Table 7.

companies initially push their products to customers. Currently, it has become a conversation between companies and customers. This means customers work together with companies to create a suitable and valuable experience for
2014:3731

Heath, Singh \& Ganesh, 2014:585,

588,589 
The more detailed processed data can be seen in Table 8 .

\begin{tabular}{|c|c|c|c|}
\hline \multicolumn{2}{|c|}{$\begin{array}{l}\text { Dimension/Indicator I as community with mutual } \\
\text { Interest/practice, consisting of people } \\
\text { who } \\
\text { interact one another on certain domain, } \\
\text { for example: profession club }\end{array}$} & $\begin{array}{l}\text { Greenberg, 2010:44 } \\
\text { Mohan, Choi \& Min, 2008: } 242 \\
\text { Heath, Singh \& Ganesh, 2014:590, } \\
592 \\
\text { Olivera, Sita \& Sasa, 2013:347-351 } \\
\text { Mousavi \& Demirkan, 2013: } 720\end{array}$ & 22 \\
\hline Communities & $\begin{array}{l}\text { A group of people who has a specific } \\
\text { mutual characteristic }\end{array}$ & $\begin{array}{l}\text { Mohan, Choi \& Min, 2008: } 242 \\
\text { Heath, Singh \& Ganesh, 2014:588 } \\
\text { Olivera, Sita \& Sasa, 2013:351 } \\
\text { Mousavi \& Demirkan, 2013: } 720\end{array}$ & 23 \\
\hline $\begin{array}{l}\text { Collabora- } \\
\text { tion }\end{array}$ & $\begin{array}{l}\text { Relationship of one another which gives } \\
\text { valuable benefits }\end{array}$ & $\begin{array}{l}\text { Greenberg, 2010:44 } \\
\text { Mohan, Choi \& Min, 2008: } 240\end{array}$ & 24 \\
\hline Context & $\begin{array}{l}\text { How a previously-made profile will be } \\
\text { used to define what is intended, what } \\
\text { is seen, and how it is seen, for instance: } \\
\text { status is made to let other people know } \\
\text { what we need }\end{array}$ & $\begin{array}{l}\text { Greenberg, 2010:45 } \\
\text { Bekmamedova \& Shanks, } \\
\text { 2014:3730, } 3732 \\
\text { Heath, Singh \& Ganesh, 2014:585, } \\
\text { 588, 589, 590 } \\
\text { Olivera, Sita \& Sasa, 2013:348 } \\
\text { Olivera, Sita \& Sasa, 2013:351 } \\
\text { Mousavi \& Demirkan, 2013: } \\
\text { 718-724 }\end{array}$ & 25 \\
\hline
\end{tabular}

Social Media Adoption for Social CRM in Higher

Education: an Insight from Indonesian Universities
Table 8.

IPA based on respondents' valuation

According to the Table 8, there are 9 dimensions/indicators (green color highlight) in category D (effective use - low performance, high importance): social media account, institution identity, official photos, official videos, comments, bookmarks, reputation, relationship and context. While in category $\mathrm{C}$ (missing opportunity/gap low performance, high importance), there are eight dimensions/indicators: social tags/ folksonomies, rating, ranking/indexing, wikis, podcasts, email, forum and presence/ instant messaging. Thus, category $\mathrm{C}$ needs to be the main priority due to its high respondents' expectation value, but with a low implementation value.

\subsection{Discussion}

The research results show the existing problem: web 2.0 and social media adoption have been accomplished by universities, but have not reached an optimal result. As seen 
IJSR

4,2 in Table 3, there are only 3 features which are above $60 \%$ : realtime webcast of events, widgets and social network for the users of the university website. The presence of social media has reached a good result for Facebook page, LinkedIn and Twitter (above $70 \%$ ). The usage and effectivity in social media shows a better result, based on the average number of followers/fans and activities done by the social media accounts (see Table 4). It is in accordance with the previous research by Bonson et al. (2012) that web 2.0 and social media have been paid more attention to by universities especially in order to maintain communication, but the usage has not been managed optimally.

The perception of social media importance and implementation level on Social CRM in universities in Indonesia has been good enough (only 3 dimensions/indicators need to be improved) and shows a similar perception in observing the dimensions/indicators considered as the most essential (there are 9 dimensions/indicators). This is parallel with the previous research done by Greenberg (2010) about social stack in building social CRM.

Based on Table 8 and entropy calculation in Table 5, there are dimension/indicator similarities on the top 9 position even though the order is a little bit different (green color highlight). On the 10th position and afterwards, things are completely different. This happens because the importance opinions according to respondents have possessed the similar indicator in observing social media application on Social CRM implementation. A consistent result can be seen as well when Table 6 and table 6 are being compared to find out areas which need to be improved by universities. The areas themselves are: social tags/ folksonomies, ranking/indexing, wikipedia and podcast (orange color highlight).

These research results show that social media has a positive impact on makerting because social media is a competitive marketing tool able to attract new customers and retain old customers (Öztamur and Karakadilar, 2014).

\section{Implication}

According to the detailed discussion above, more people are using social media to maintain relationships with others and to look for information. On the other hand, the information provided by universities is still in one-way attribute and not optimal yet. That is why universities have to pay more attention to the content quality which will be delivered to society, students and student candidates. Regarding web 2.0 and social media adoption, universities need to improve on several things: social tags/ folksonomies, wikis and podcast. A personally-managed content classification by users will be assisting them when finding the desired information (social tags/folksonomies). Users will be able to edit the content altogether at once in the website, thus a complete information will be provided (Wikis) and audio files could be obtained by subscribing or downloading them into computer or wireless music device. This will help customers with listening and repeating the desired contents (podcast).

The implication of this research on science is an emphasis on the previous researches indicating that social media usage is very important in implementing Social CRM because it acts as a supporting tool to listen to customers' conversation (Askool and Nakata, 2010; Greenberg 2010). However, the usage is not optimal yet because it just relies on the communication not as a principal in developing an organization's website (Benson et al., 2012). 


\section{Limitation and Further Research}

The limitation of this research is that the number of university respondents should be enlarged and taken not only from Jakarta but from all over Indonesia. The initial selection of respondents was only universities in Jakarta because of considerations of competence and capability of the university as well as the availability of adequate Internet infrastructure.

Further studies of this research is to find the preference of social media usage from the perspective of prospective students, students and alumni. These preferences will help universities to select and define the social media that will be provided by the university in order to assist customers in finding information for choosing the university and to enhance customer engagement.

\section{Conclusion}

To conclude, the adoption of web 2.0 and social media has been done by universities on their websites. The web 2.0 usage has not been fully optimal, since only two out of five features have reached more than $80 \%$ : realtime webcast of events and widgets; and one feature has not been used at all: podcast from the management $(0.00 \%)$. Social media usage shows higher universities' euphoria in exploiting social media as one of the communication channels towards the society, students and student candidates. All universities are utilizing Facebook page (100.00\%) and many LinkedIn (84.48\%), Twitter $(70.69 \%)$ and YouTube $(51.72 \%)$. However, the attached social media links which are used in their offical websites are not optimal yet because not every one of them publish their social media links in their websites (only 67.24\%). The social media has been used for daily activities on Facebook and Twitter.

Based on importance-performance analysis (IPA), there are nine good dimensions/ indicators which need to be maintained (owning social media account, university's identity, offical photos, official video, relationship, bookmarks, reputation, context and comments) and three dimensions/indicators which need to be improved: social tags/ folksonomies, wikis and podcast.

In the future, universities have to work on some improvements: publishing social media accounts on their websites, intensify social media usage as the source of trusted information and updating daily information (daily activities), putting social media as a tool to capture customers' conversation in order to recognize their needs, maximizing YouTube in delivering digital contents (videos) about the university, improving social media function (social tags/folksonomies, wikis and podcast) to increase the number of customers who are willing to to join the official universities' social media.

\section{Acknowledgement}

The abstract of this paper has been presented and published at the MakeLearn and TIIM 2015 International Conference.
Social Media Adoption for Social CRM in Higher Education: an Insight from Indonesian Universities 
IJSR

4,2

\section{References}

Askool, S.S. and Nakata, K. (2010). Scoping Study to Identify Factors Influencing the Acceptance of Social CRM, Proceedings of International Conference on Management of Innovation and Technology (ICMIT) in Singapore, IEEE, pp. 1055-1060.

DOI: http://dx.doi.org/10.1109/icmit.2010.5492888

Asl, M.B., Khalilzadeh, A., Youshanlouei, H.R., Mood, M.M. (2012). Identifying and ranking the effective factors on selecting Enterprise Resource Planning (ERP) system using the combined Delphy and Shannon Entropy approach, Procedia - Social and Behavioral Sciences, Vol. 41, pp. 512-530. DOI: http://dx.doi.org/10.1016/j.sbspro.2012.04.063

Bonsón, E., Torres, L., Royo, S., Flores, F. (2012). Local e-government 2.0: Social media and corporate transparency in municipalities, Government Information Quarterly, Vol. 29, pp. 123-132. DOI: http://dx.doi.org/10.1016/j.giq.2011.10.001

Boyd, D.M. and Ellison, N.B. (2007). Social Network Sites: Definition, History, and Scholarship, Journal of Computer-Mediated Communication, Vol. 13 No. 1, pp. 210-230.

DOI: http://dx.doi.org/10.1111/j.1083-6101.2007.00393.x

Brandt, D.R. (2000). An "Outside-In" Approach to Determining Customer-Driven Priorities for Improvement and Innovation, White Paper Series, Vol. 2.

Burns, K.S. (2008). A historical examination of the development of social media and its application to the public relations industry. Proceedings of The International Communication Association Conference in Montreal, Canada.

Castells, M. (2013). Communication Power, Oxford University Press, Oxford, United Kingdom.

Davis III, C.H.F., Deil-Amen, R., Rios-Aguilar, C., González Canché, M.S. (2012). Social media and higher education: A literature review and research directions, Report printed by the University of Arizona and Claremont Graduate University.

Doyle, A. (2012). Social Media Definition. Retrieved December 29, 2012 from http://jobsearch.about.com/od/networking/g/socialmedia.htm

Greenberg, P. (2010). CRM Customer Relationship Management, Social CRM Strategies, Tools, and Techniques for Engaging Your Customers, at the Speed of Light, 4th Edition, McGrawHill Osborne.

Harris, A.L. and Rea, A. (2009). Web 2.0 and Virtual World Technologies: A Growing Impact on IS Education, Journal of Information Systems Education, Vol. 20 No. 2, pp. 137-144.

Hennig-Thurau, T., Malthouse, E.C., Friege, C., Gensler, S., Lobschat, L., Rangaswamy, A., Skiera, B. (2010). The Impact of New Media on Customer Relationships, Journal of Service Research, Vol. 13 No. 3, pp. 311-320. DOI: http://dx.doi.org/10.1177/1094670510375460

Hsu, P.F. and Hsu, M.G. (2006). Optimizing the Information Outsourcing Practices of Primary Care Medical Organizations Using Entropy and TOPSIS, Hsin Chu City: Yuanpei University.

Kaplan, A.M., and Haenlein, M. (2010). Users of the World, Unite! The Challenges and Opportunities of Social Media, Business Horizons, Vol. 53, pp. 59-68.

DOI: http://dx.doi.org/10.1016/j.bushor.2009.09.003

Kozinets, R.V. (1999). E-tribalized marketing?: The strategic implications of virtual communities of consumption, European Management Journal, Vol. 17 No. 3, pp. 252-264.

DOI: http://dx.doi.org/10.1016/S0263-2373(99)00004-3

Latu, T.M. and Everett, A.M. (2000). Review of Satisfaction Research and Measurement Approaches, Departement of Conservation, Wellington, New Zealand.

Martinez, C.L. (2003). Evaluation Report: Tools Cluster Networking Meeting \#1, CenterPoint Institute, Inc., Arizona.

Mohan, S., Choi, E., Min, D. (2008). Conceptual Modeling of Enterprise Application System Using Social Networking and Web 2.0 Social CRM System, Proceedings of International 
Conference on Convergence and Hybrid Information Technology (ICHT) in Daejeon, South Korea, 2008, IEEE, pp. 237-244.

O'Really, T. (2005). What is Web 2.0: Design patterns and business models for the next generation of software. Retrieved January 2010 from http://oreilly.com

DOI: http://dx.doi.org/10.1109/ICHIT.2008.263

Patel, K. (2013). Incremental Journey for World Wide Web: Introduced with Web 1.0 to Recent Web 5.0 - A Survey Paper, International Journal of Advanced Research in Computer Science and Software Engineering, Vol. 3 No. 10, pp. 410-417.

Patoine, M. and Pen, A. (2012). Leveraging Social CRM as a Viable Customer Service Channel. Retrieved December 27, 2012

from http://www.callcentre.co.uk/files/top 50 webinar_16 feb 2012 social crm siemens.pdf

Reuben, R. (2008). The Use of Social Media in Higher Education for Marketing and Communications: A Guide for Professionals in Higher Education, California State University, Fullerton.

Shirouyehzad, H., Khodadadi-Karimvand, M. Dabestani, R. (2011). Prioritizing Critical Success Factors Influencing Safety, Using TOPSIS, International Journal of Business and Social Science, Vol. 2 No. 20, pp. 295-300.

Sigala, M. and Chalkiti, K. (2014). Investigating the exploitation of web 2.0 for knowledge management in the Greek tourism industry: An utilisation-importance analysis, Computers in Human Behavior, Vol. 30, pp. 800-812. DOI: http://dx.doi.org/10.1016/j.chb.2013.05.032

Statistica. (2015). Number of monthly active mobile social media users in Asia Pacific as of January 2014 by country. Retrieved January 13, 2015 from http://www.statista.com/statistics/295643/mobile-social-media-mau-asia-pacific-countries/

Wardhani, I.K., Usadha, I.G., and Irawan, M.I. (2012). Seleksi Supplier Bahan Baku dengan Metode TOPSIS Fuzzy MADM (Studi Kasus PT. Giri Sekar Kedaton, Gresik, Surabaya), Jurnal Sains dan Seni Pomits, Vol. 1 No. 1, pp. 1-6.

Zou, Z., Yun, Y., Sun, J. (2006). Entropy method for determination of weight of evaluating indicators in fuzzy synthetic evaluation for water quality assessment, China: Beihang University.

\section{Biographical notes:}

Meyliana has been the faculty member of the School of Information Systems Bina Nusantara University since 1997. Her research interests are business process management, enterprise system, customer relationship management, e-business and information system development. She graduated from Master in Management of Information Systems from Bina Nusantara University and now she is a Ph.D candidate in Computer Science at the University of Indonesia. Currently she is the Deputy Vice Rector Operational of Alam Sutera Campus and Rector's Office Manager at Bina Nusantara University.

Achmad Nizar Hidayanto is the Head of Information Systems/Information Technology Stream at the Faculty of Computer Science at the University of Indonesia. He received his $\mathrm{PhD}$ in Computer Science from the University of Indonesia. His research interests are information systems/information technology, e-learning, information systems security, customer relationship management, change management, distributed systems and information retrieval.
Social Media Adoption

for Social CRM in Higher

Education: an

Insight from

Indonesian

Universities 
IJSR

4,2
Eko K. Budiardjo has been the faculty member of the Faculty of Computer Science at the University of Indonesia since 1985. Teaching, research, and practical services are aligned and result in a full spectrum of academic achievement. Majoring in Software Engineering as professional track record, he has made some scientific contribution such as Software Requirement Specification (SRS) patterns representation method, ZEF Framework and FrontCRM Framework. Graduated from Bandung Institute of Technology (ITB) in 1985, holds Master of Science in Computer Science from the University of New Brunswick, Canada received in 1991 and was awarded Philosophical Doctor in Computer Science at the University of Indonesia in 2007. Currently he is the Vice Chairman of ICT Technical Committee of The National Research Council (DRN) and Chairman of The Indonesian ICT Profession Society (IPKIN). 